\title{
Gabriel Cid Rodríguez. Pensar la revolución. Historia intelectual de la independencia chilena, Santiago, Ediciones Universidad Diego Portales, 2019, 434 págs.
}

El libro de Gabriel Cid, Pensar la revolución. Historia intelectual de la independencia chilena, que es la adaptación de la tesis doctoral del autor, profundiza en los conceptos e ideas que los criollos chilenos desplegaron durante los momentos críticos de la independencia y los primeros años de la vida republicana. Esta profundización le permite a Cid comprender el tiempo histórico y el final de la revolución, con la consolidación republicana. La metodología de este trabajo se enmarca en las herramientas de la Escuela de Cambridge, la historia conceptual y la historia de lo político; categorías que permiten comprender el espacio de lo político, los elusivos y variables significados de los nuevos conceptos invocados durante el periodo. En efecto, el análisis del lenguaje político presente en la prensa del periodo le permite a Cid reconstruir los problemas políticos que tuvieron los patriotas intelectuales durante la independencia y la república.

Lo primero que se advierte, ya desde la introducción, es que el autor busca estudiar los diálogos entre diversas tradiciones de pensamiento político que se originaron en este periodo de crisis. La evolución de los lenguajes políticos, la argumentación provenida de tradiciones liberales, republicanas o neoescolásticas, pasan inadvertidos por la historiografía chilena, incluso el propio autor plantea: "estas argumentaciones se han tendido a llamar "liberalismo hispánico", la tradición iusnaturalista o la importancia de la teología política" (Cid, 2019: 22). Por lo tanto, al tomar estas categorías, se pueden comprender otros fenómenos que nos permiten discernir el quiebre con la península ibérica; el colapso de la metrópoli fue la que originó un vacío de poder que obligó a los criollos a justificar esta situación, los patriotas intelectuales utilizaron el liberalismo como lenguaje político para encontrar respuestas a los problemas políticos que vivían durante ese periodo.

El autor se propone recuperar el problema de lo político como parte de la dinámica conflictiva de las primeras décadas del siglo XIX, porque contribuye a complejizar el escenario historiográfico, la "herencia colonial", la falta de experiencia de los criollos en los principios del autogobierno, el conflicto regional, las tensiones interclasistas, la divergencia de intereses económicos, el faccionalismo, la militarización y la personalización de la política en la época. El despliegue de problemas, ideas y hechos contribuyen a comprender mejor las expectativas, temores, pasiones y razones de los actores políticos de la independencia chilena durante los años 1810 y 1833, periodo que marca el final de la revolución.

El libro se divide en tres partes, ordenadas de acuerdo con el desarrollo de la revolución de la independencia chilena: la primera parte, "Hacer la revolución", que va desde 1808 a 1817; la segunda parte "Implementar la revolución”, de 1818 a 
1828; y la tercera parte, "Finalizar la revolución", aborda el cierre de este proceso político que va desde 1829 a 1833.

La primera parte, constituida por tres capítulos, analiza el lapso que transcurre desde la recepción de las noticias de las abdicaciones de Bayona, hasta la declaración de la independencia. Durante este proceso, la reflexión política se insertó en el marco conceptual de la monarquía, esta última buscaba, además, el retorno al absolutismo durante el proceso de la "Reconquista". El autor muestra que los criollos no deseaban del todo la Independencia, esto se expresaba en la fidelidad a la corona española durantela prisión de Fernando VII. El deseo de no separarse de la metrópoli y mantener la obediencia a Fernando VII y a sus legítimos sucesores, como sostenía Bernardo de Vera y Pintado. Por lo tanto, los patriotas abrieron un debate en torno a la soberanía, lo que derivó en torno a la instauración de la Junta Gubernativa en Chile, en septiembre de 1810, en un escenario que enfrentó al Cabildo santiaguino con la Real Audiencia. Estas disputas ocasionaron que la fragmentación imperial fracasara, sobre todo el proyecto republicano de Camilo Henríquez. Este derrotero republicano llevó a Henríquez a escribir su "Ensayo acerca de las causas de los sucesos desastrosos de Chile", donde explicó los motivos por los cuales Chile no era compatible con el republicanismo: la aristocracia no poseía ilustración y desconocía las obras filosóficas, y no había apoyo popular, porque se beneficiaban de la causa monárquica, se prefería adorar el nombre del rey, sin observar cual era la ley y quien es Dios (Cid, 2019: 93). En síntesis, con gran acierto Cid logra problematizar el panorama político del
Chile revolucionario, expresando finalmente que el independentismo y republicanismo tuvieron una relación de dependencia.

La segunda parte de la reflexión política corresponde al decenio que va desde la Declaración de la Independencia a la Constitución de 1828. Cid dialoga en el marco de la opción republicana y de la monarquía constitucional de los patriotas. La independencia podía ser relativa o absoluta; podía referirse a España, pero en diversos escenarios posibles, ocupada completamente por los franceses o libres, también referirse a instituciones representativas como las Cortes, o ejecutivas como la Regencia, pero no de Fernando VII; o bien independencia como disolución total del vínculo imperial. Las discusiones de los patriotas en torno a estos dilemas son bien logradas en este capítulo. Cid demuestra los motivos de los rechazos al establecimiento de las juntas en América, el cual sería el tratamiento injusto de los americanos, sumado a que estos mismos patriotas buscaban lograr una postura separatista. El análisis de Cid se extiende más en cuanto a las guerras de independencia, la paradoja del republicanismo, y el lenguaje político de la contrarrevolución. En este punto, se de- muestra que la experiencia del exilio y de la contrarrevolución volverían impensables cualquier intento de conciliación política e ideológica, elementos que en su estudio se vuelven muy interesantes de conocer porque se logra comprender que la revolución tenía como propósito desbaratar el Antiguo Régimen.

La tercera parte, se sitúa entre la guerra civil de 1829 1833, con la sanción de la última constitución del siglo XIX chileno. Esta parte es, a mi juicio, 
una de las más logradas del libro, pues analiza las reflexiones políticas de los intelectuales de la época como fin de la experimentación ideológica tras la declaración de la independencia, logrando afianzar los logros de la revolución. La reflexión política del nuevo grupo detentor del poder, imbuido por una sensibilidad conservadora y expresando un desengaño respecto a los derroteros del experimento republicano en Hispanoamérica, encuentran un espacio en donde finalizar la revolución sin desechar sus principios básicos. La revolución finaliza con la instauración de la constitución. Me parece que estos últimos capítulos recogen con mayor fuerza el punto de apoyo de la revolución, esto se puede observar en la solución constitucional, el cual fue reforzar la autoridad presidencial, buscar la libertad y poner fin al proceso revolucionario, los cuales son analizados con gran acierto bajo el estudio de la prensa del periodo.

En suma, el texto aquí presentado constituye un estudio indispensable no solo para los interesados en el proceso de la independencia y de la república, sino también para aquellos que quieran conocer como se pensó la revolución desde lo intelectual y lo político. En otros términos, estamos frente a una investigación solida (teórica, metodológica y empírica), que nos permite entender el panorama de la política chilena durante la independencia y su transición a la república. Por lo tanto, la investigación de Gabriel Cid abre nuevos caminos para entender la independencia desde las ópticas de la política y lo conceptual que desarrollaron los actores históricos durante la construcción del proceso republicano. Por otra parte, también invita a los historiadores e historiadoras a comprender, pensar y problematizar la historia política e intelectual con nuevas preguntas, metodologías y enfoques novedosos. Para finalizar, el estilo narrativo de Gabriel Cid es claro y comprensible para aquellos que no están habituados a estudiar los lenguajes y teorías políticas, por lo que lo acerca a un público lector que necesariamente académico.

Jorge Orellana Billiard Programa de Doctorado en Historia, Pontifica Universidad Católica de Valparaíso. 